\section{Capital Ungoverned}

\section{Reputation and International Politics}

\section{JONATHAN MERCER}

"By applying the insights of social psychology to the problem of how reputations form and are maintained, Mercer makes a clear and persuasive argument that every actor has multiple reputations, that a reputation for resolve is more easily maintained among adversaries than among allies, and that the protection of reputation is never a sufficient reason to go to war. ... This excellent book is well written, detailed, and thought-provoking."-Choice Cornell Studies in Security Affairs $\$ 35.00$

\section{Liberalizing Finance in Interventionist States \\ MICHAEL LORIAUX, MEREDITH \\ WOO-CUMINGS, KENT CALDER, SYLVIA MAXFIELD, AND SOFÍA PÉREZ}

The authors assess the internal and global changes that prompted Japan, South Korea, Mexico, France, and Spain to adopt financial liberalization. "A first-rate book. It represents the cutting edge of research in political economy and groups together in a single volume some of the most original research to date on the politics of financial liberalization." -HARVEY B. FEICENBAUM, George Washington University $\$ 39.95$ cloth, $\$ 15.95$ paper

\section{NarcoDiplomacy}

Exporting the U.S. War on Drugs

\section{H. RICHARD FRIMAN}

If illicit drug trafficking is a global problem, why won't other nations comply with the drug control agenda of the United States? NarcoDiplomacy departs from traditional responses to this question, which have held that compliance with the American agenda has been beyond the capacity of key countries. By focusing on Germany and Japan, touted as two of the strongest allies of the United States in drug control efforts, Friman exposes the flaws in capacity arguments and the policies based on them. "A significant contribution to what we know about the history of international drug control and U.S. drug policy. NarcoDiplomacy is also analytically superior to existing scholarship on drugs." -WILLIAM O. WALKER III, Ohio Wesleyan University $\$ 29.95$

\section{Freer Markets, More Rules}

\section{Regulatory Reform in Advanced \\ Industrial Countries \\ STEVEN K. VOGEL}

"Vogel writes with extraordinary clarity about a very complex subject. His discussion of deregulation not only gives the reader a clear understanding of the distinct issues of market liberalization and regulatory reform as they have been pursued in Japan, it also offers a nuanced analysis of the relationship between state and market in contemporary lapan. Vogel brings a comparative perspective to this analysis that makes his book especially important for anyone interested in developing a better understanding of Japan's political economy." - GERALD L. CURTIS, Columbia University. $\$ 35.00$

\section{National Interests in International Society}

\author{
MARTHA FINNEMORE
}

"This book offers a powerful challenge to liberal and realist approaches to international relations. Many writers have asserted that social structures exert a powerful impact on national preferences (and international outcomes), but Finnemore is the first to present sophisticated evidence for this claim. Readers of all intellectual persuasions will enjoy grappling with her clear-eyed, trenchant, and beautifully written argument, and should expect to come away rethinking their positions." — STEPHEN M. WALT, University of Chicago $\$ 35.00$ cloth, $\$ 13.95$ paper

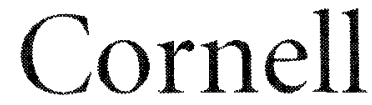




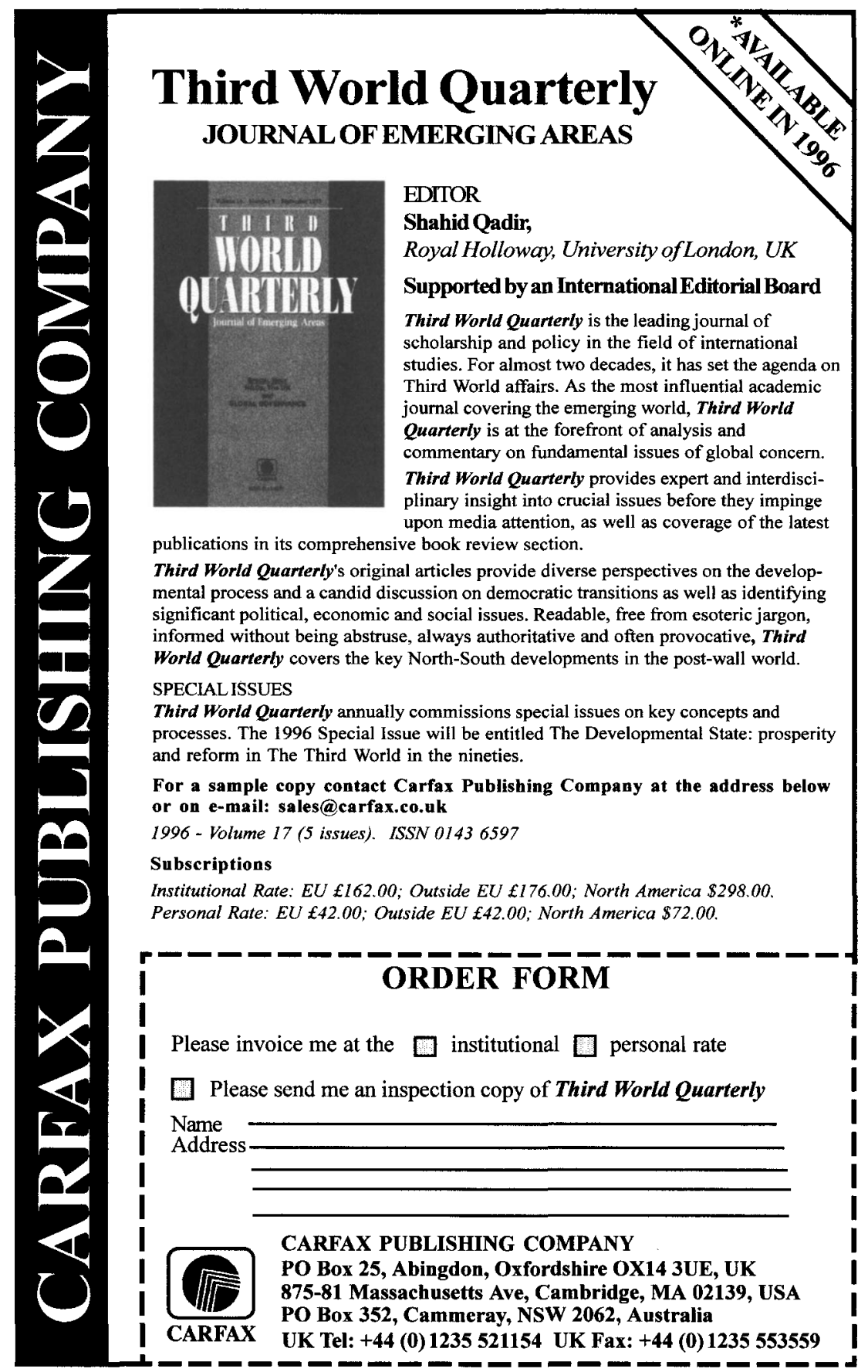




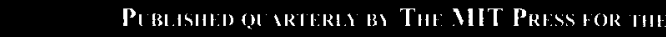

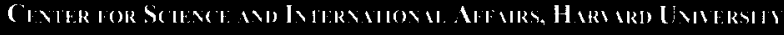

\section{Celebrating Twenty Years of Publication, 1976-1996 International Security}

"For twenty years IS has been influencing scholarship and public discourse. On a wide range of topics, it has become our most interesting and important journal." ROBERT JERVIS

Columbia University

"The best journal in the field." KENNETH WALTZ University of California, Berkeley

"Absolutely indispensable." SAMUEL P. HUNTINGTON Harvard University

"IS is the best journal in the national security field, without question."

-ROBERT J. ART

Brandeis University
Steven E. Miller, Editor in Chief

Michael E. Brown, Managing Editor

Sean M. Lynn-Jones and Owen R. Coté, Editors

For twenty years, International Security has published articles that have defined the debate on all aspects of war, peace, and security studies. Its lucid and well-documented essays come from all political and theoretical perspectives. Subscribers receive the most provocative and most frequently cited articles on today's security agenda.

Recent contributors include: Charles Glaser, Thomas Homer-Dixon, Josef Joffe, Robert Keohane, Elizabeth Kier, Stephen Krasner. Charles Kupchan, Edward Mansfield. Lisa Martin, John Mearsheimer, Richard Rosecrance, Stephen Peter Rosen, and Jack Snyder.

Visit MIT Press's World Wide Web site at: http://www-mitpress.mit.edu

0 Check or money order - payable to lntenctional Security. drawn on a US bank in U.S. funds - is enclosed.

7 Please begin my one-year subscription (4 issues, first issue of current volume) to linternation of Security.

This is a new subscription.

G This is a renewal. My account number is (see issue label),

1996 Rates (check one) I year (4 issues) Prices subject to change without notice frepoyment reguired.

$$
\text { US. Canada All Other }
$$

$\begin{array}{lrrr}\text { Individual } & \$ 36 & \$ 55.64 & \$ 52 \\ \text { Institution } & \$ 96 & \$ 119.84 & \$ 112 \\ \text { Studerttok/Retired } & \$ 20 & \$ 38.52 & \$ 36\end{array}$

*Prices reflect shipping and handfing phus $7 \%$ GST **Copy of current ID required.

Address all subscription inquiries to: MIT Press fournals

55 Hawward Street, Cambridge, MA 02 142 USA Tel 617. 253 2889 Fax: 617.577 .1545 journals-orders@mited
Charge to my $\triangle$ AMEX $\square M C D$ VISA

Acct $\mathrm{Na}$

Exp Date

Signature/Toda/s Date

Phint Cardholders Name

Send to (please print clearty):

Name

Company/Department

Address

Country

Daytime Phome
Ciny/Sare Z ZlP/Province 
"The oldest and greatest of the social science journals in America." - Arthur Link, Princeton University

\section{POLITICAL SCIENCE QUARTERLY}

THE JOURNAL OF PUBLIC AND INTERNATIONAL AFFAIRS

"Most serious journals are narrow; most journals which are broad in scope are not serious. PSQ is the exception: a joumal which is both broad in scope and serious in content. It is must reading for social scientists and informed citizens interested in public affairs."

- Samuel Huntington, Harvard University

"The articles and book reviews in PSQ are intelligent, timely, and well written. They range over many vital topics. I find much to engage my interest in every issue."

- Theda Skocpol, Harvard University

"I am delighted to have been a member of the Academy of Political Science since 1967... I have always found Political Science Quarterly to be an extremely valuable tool for research and analysis." - Bill Green, member of Congress, 1978-1993

"The Political Science Quarterly is simply the best general journal in the field."

- Richard K. Betts, Columbia University

"Everyone interested in expert commentary on and acute analysis of governance at home and abroad will find sustenance and illumination in the pages of that distinguished and eminently readable journal, the Political Science Quarterly."

- Arthur Schlesinger, Jr., Historian

\section{Subscribe now by joining the Academy of Political Science} Name.

Address

City. State Zip.......

Telephone.

$\square$ Check enclosed. Charge my: $\square$ Am Ex $\square$ Visa $\square$ Mastercard Card Number. Exp. Date. Signature.

$\square 1$ year $(\$ 39) \quad \square 2$ years $(\$ 70) \quad \square 3$ years $(\$ 93)$

$\square$ Student (\$27) $\square$ Institution (\$146)

Outside USA add $\$ 8 / y r$. Payment must be in US currency.

The Academy of Political Science

475 Riverside Drive Suite, $1274 \cdot$ NY NY 10115

PHONE (212) 870-2500 / FAX (212) 870-2202 / EMAIL APS321(a),AOL.COM 


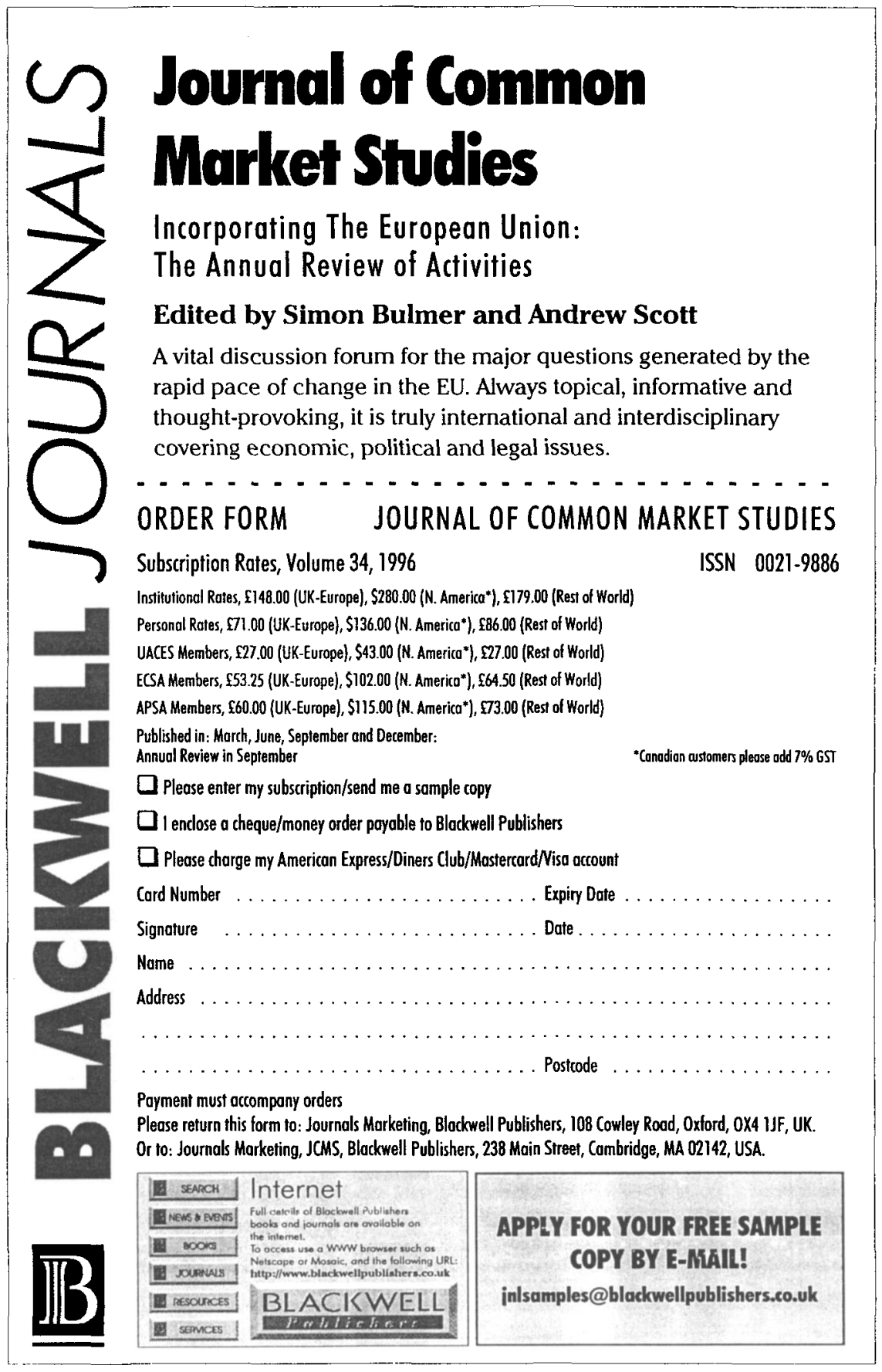




\section{Now Published by Blackwell!}

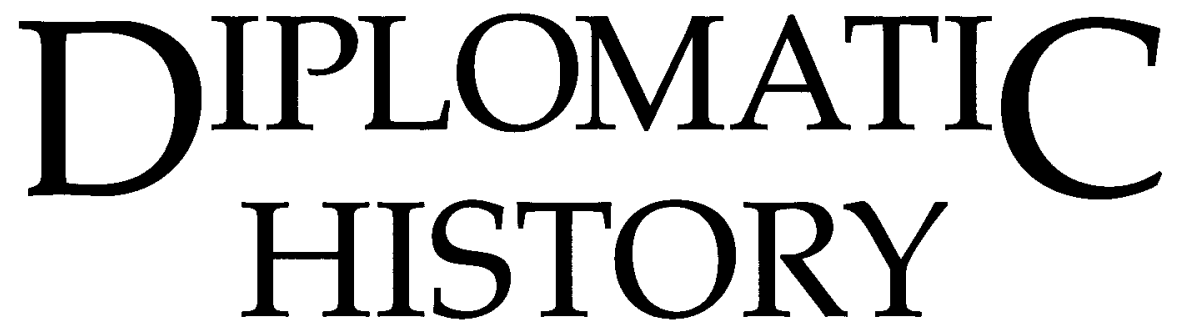

Edited by

MICHAEL HOGAN

The Ohio State University

Diplomatic History, the journal of record of the Society for Historians of American Foreign Relations, is the only journal devoted to US international history and foreign relations, broadly defined, including grand strategy, diplomacy, and issues involving gender, culture, ethnicity, and ideology. It examines US relations in a global and comparative context, and its broad focus appeals to a number of disciplines including political science, international economics, American history, national security studies, Latin American, Asian, African, and European studies.

Published in January, April, July, October

ISSN 0145-2096

Prices for Volume 20:

Institutions: $\quad \$ 75.00$ (N. America)

$\$ 90.00$ (Rest of World)

Individuals: $\quad$ NA (N. America)

NA (Rest of World)

Journals Dept.

Blackwell Publishers

238 Main Street

Cambridge, MA 02142

E-Mail: blackwell.subscriptions@world.std.com

CALL TOLL-FREE

(800) 835-6770
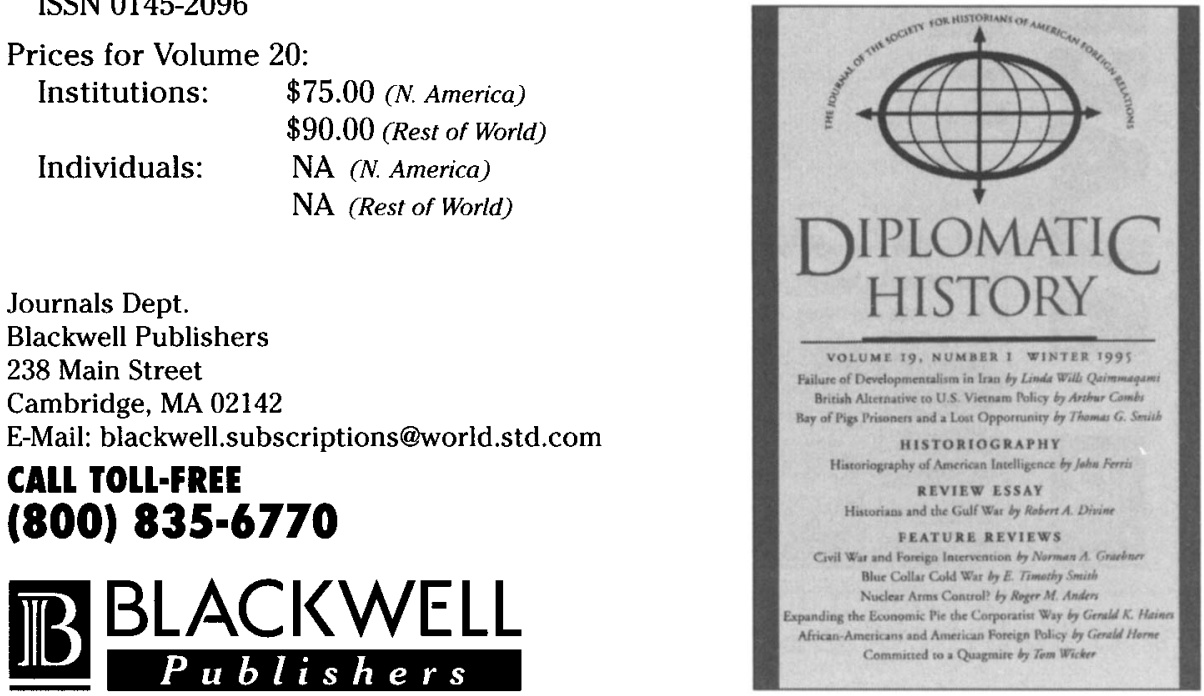
International Organization (ISSN 0020-8183) is published quarterly (winter, spring, summer, and autumn) by The MIT Press, Cambridge, MA 02142. Subscriptions and address changes should be addressed to MIT Press Journals, 55 Hayward Street, Cambridge, MA 02142; (617) 253-2889; e-mail: journals-orders@mit.edu. Subscriptions are on a volume year basis. Rates are: Individual $\$ 38.00$, Institutions $\$ 100.00$, Students/Retired $\$ 25.00$. Outside U.S. add $\$ 16.00$ for postage and handling. Canadians add additional 7\% GST. Current issues are $\$ 26.00$. Back issues are: Individuals: $\$ 13.00$, Institutions $\$ 26.00$. Outside U.S. add $\$ 5.00$ per issue for postage and handling. Canadians add additional 7\% GST. Claims for missing issues will be honored free of charge if made within three months after the publication date of the issue. Prices subject to change without notice.

International Organization is abstracted or indexed in the following: Academic Abstracts, ABC Pol Sci, America: History and Life, Applied Social Sciences Index \& Abstracts, Communication Abstracts, Current Contents/Social \& Behavioral Sciences, Current Law Index, Deep Sea Research \& Oceanographic Abstracts, Energy Research Abstracts, Expanded Academic Index, Future Survey, Historical Abstracts, Human Rights Internet Reporter, INIS Atomindex, Index of Economics Articles, International Bibliography of Economics (also in IBSS), International Bibliography of Periodical Literature, International Bibliography of the Social Sciences/Political Science, International Labour Documentation, International Political Science Abstracts, Journal of Economic Literature, Key to Economic Science, Legal Research Index, Magazine Index (Information Access Company), Middle East: Abstracts and Index, Public Affairs Information Service/PAIS, Recently Published Articles, Rural Recreation and Tourism, SCIMP (Selective Cooperative Index of Management Periodicals), Social Sciences Citation Index, Social Sciences Index, Social Science Source, Sociological Abstracts, World Agricultural Economics \& Rural Sociology Abstracts.

Advertising and mailing list rental: Please write to Marketing Manager, MIT Press Journals, 55 Hayward Street, Cambridge, MA 02142 USA, or telephone (617) 253-2866, email: journals-info@mit.edu.

Rights and permissions: All inquiries concerning rights and permissions should be sent to Subsidiary Rights Manager, MIT Press Journals, 55 Hayward Street, Cambridge MA 02142; e-mail: journals-rights@mit.edu. Permission to photocopy articles for internal or personal use or the internal or personal use of specific clients is granted by The IO Foundation and the Massachusetts Institute of Technology for libraries and other users registered with the Copyright Clearance Center (CCC), provided that the fee of $\$ 8.00$ per copy is paid directly to CCC, 222 Rosewood Drive, Danvers, MA 01923. The fee code for users of the Transactional Reporting Services is 0020-8183/96 $\$ 8.00$. For those organizations that have been granted a photocopy license with CCC, a separate system of payment has been arranged. 


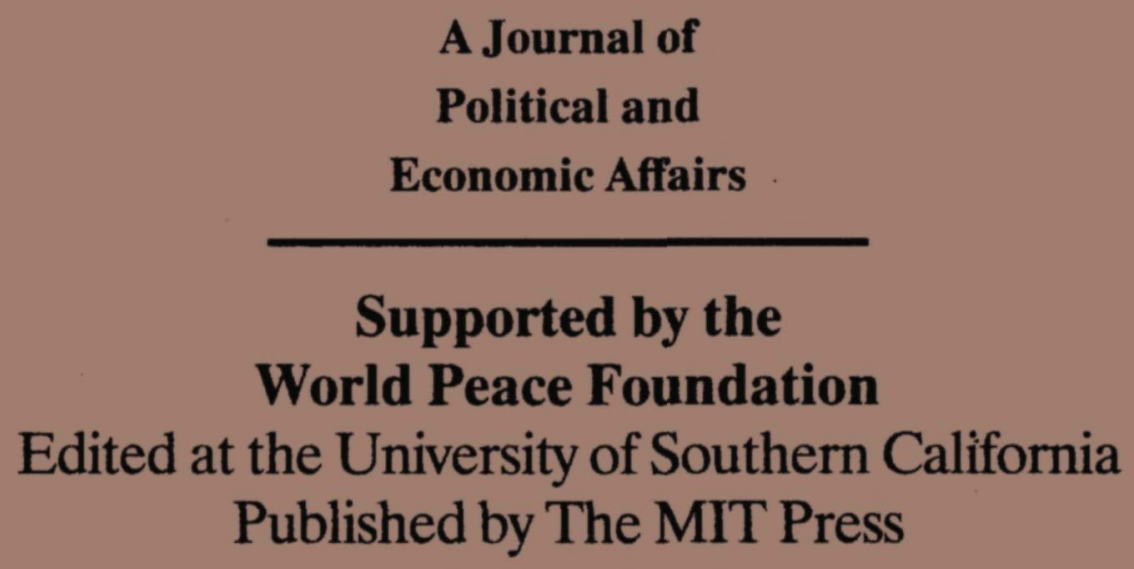

